\title{
軽量気泡コンクリート材を利用した セシウムイオン交換材料の開発
}

\section{亀島 欣一*, 堤 卓馬, 西本 俊介, 三宅 通博}

国立大学法人岡山大学大学院環境生命科学研究科 資源循環学専攻

干700-8530 岡山県岡山市北区津島中 3-1-1

（受理日：2013 年 4 月 1 日）

\begin{abstract}
要 旨
福島第一原子力発電所の事故により環境中に放出されたセシウム等の除去, 回収, および固定化に向けた材料が必 要とされている。著者らの研究グループでは, トバモライトが主成分である軽量気泡コンクリートを基材としたセシ ウム吸着・固定化材料を開発してきた。トバモライトを水酸化ナトリウムで処理することで, 高いセシウム除去性能 が発現する。ここでは, この試料の粉末とバルク体でのセシウム・ストロンチウム除去性能, 怙よびそれらを用いた 海水中からのセシウム・ストロンチウムの除去性能について解説する。

キーワード : 軽量気泡コンクリート, トバモライト, イオン交換, セシウム, 吸着
\end{abstract}

\section{1.はじめに}

\section{1 福島第一原子力発電所を取り巻く現状}

東日本大震災，それにともなう福島第一原子力発電所の 事故以降，環境中に放出された放射性セシウム等の回収は 重要な課題である。住宅地, 農地, 森林などからセシウム を除去し, 震災前の状態に環境を回復し, 避難住民が州還 できるようにすることが重要かつ契緊の課題であり, 現在 も日夜努力が続けられている。一方, 最近の報道では原子 炬冷却水の問題が大きく取り上げられる機会が多い。しか し, 冷却水に限らず河川や周辺海域の水についても, 除染 は大きな問題となっている。ヒラメやアンコウなどの底魚 が污染されているとの報道に加え, 福島原発から離れた水 域での回遊魚からも放射能が検出されたという報道は記憶 に新しい1,2)。しかしながら, 海水中から低濃度のイオン を回収するためには, 大量のイオン交換体を長時間使用し なければならず，イオン交換性能だけでなく安価で大規模 利用が可能な材料が必要とされる。

\section{2 種々のイオン交換材料}

水系の環境中に放出されたセシウムやストロンチウム は，普通はイオン状態で存在する。そのため, これらの除 去には陽イオン交換性能をもつ材料が利用される。釈迦に 説法と思われるが, 以下にセシウムやストロンチウムの除 去に利用される材料について簡単に説明する。

\subsection{1 ゼオライト}

ゼオライト ${ }^{3)}$ はソーダライトケージと呼ばれる籠状のケ イ酸塩の骨格が複雑に構造化することでトンネル状の空隙 構造を持ったアルミノケイ酸塩のことである。高濃度污染 水の処理装置として報道されたキュリオンやサリーのセシ ウム除去はこのゼオライトを利用したものである。ゼオラ イトは， $\mathrm{SiO}_{4}$ 四面体で骨格構造を構成するが，その一部 が $\mathrm{AlO}_{4}$ 四面体に置換しており，骨格としては負電荷を帯 びている。そのため電荷補償する陽イオンがケージ内に含 まれて抢り，この陽イオンがセシウム等とイオン交換され る。このイオン交換反応では, 骨格のシリコン/アルミニ ウム比が大きい場合は 1 価の陽イオン対する選択性が高 く，小さい場合は 2 価の陽イオンに対する選択性が高 (4)。イオン交換反応時に，後述の粘土鉱物などとは異な り，イオン交換による構造変化がほとんど生じない。ま た, 回収したイオンを逆反応で取り出し, ゼオライトその ものは再利用が可能である。

\section{2 .2 粘土鉱物}

粘土鉱物5) は層状のケイ酸塩鉱物の総称であり, $\mathrm{SiO}_{4}$ 四 面体層々 $\mathrm{MO}_{6}$ 八面体層で構成される層の組み合わせで種 々の層状物質を形成することができる。各層で異種金属に よる部分置換が生じ, 通常は層が負に帯電するため, 層間 に電荷補償のための陽イオンが存在する。特に $2: 1$ 型の

\footnotetext{
* Corresponding author

E-mail : ykameshi@cc.okayama-u.ac.jp
} 
層状ケイ酸塩は，セシウム等の高い吸着性能を示す。例え ば代表的な粘土鉱物であるモンモリロナイトは $100 \mathrm{meq} /$ $100 \mathrm{~g}$ の高い陽イオン交換能を有する。しかし，吸着した セシウムイオンは外部に高濃度の他の陽イオンが存在すれ

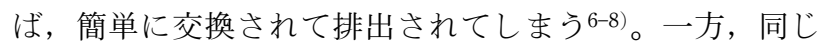
$2: 1$ 型の層状ケイ酸塩のなかでも, バイデライト ${ }^{8)}$ とバー ミキュライト ${ }^{9)}$ は，蹯水的に取り込まれたセシウムイオン がケイ酸塩層内の $\mathrm{SiO}_{4}$ 四面体 6 個で構成される環状構造 に入り込むためカリウムイオン等と同様に層間に固定化さ れる10)。しかしながら，類似の構造である雲母は，すで にカリウムにより層間が完全に閉じているために，セシウ ム等の他の陽イオンを後から取り込むことはできない。一 方, 雲母をナトリウム化することで, セシウムなどの回収 が可能となることが知られている11,12)。

\section{2 .3 その他の物質}

プルシアンブルーはフェロシアン鉄のことであり，一般 式 $\mathrm{A}_{\mathrm{y}} \mathrm{Fe}\left[\mathrm{Fe}(\mathrm{CN})_{6}\right]_{\mathrm{x}} \cdot \mathrm{z}_{2} \mathrm{O}$ （A：陽イオン）で表される 青色の人工顔料である。ゼオライトのように内部に空隙を 持つ構造をして抢り,この空隙にセシウムを取り込むこと ができる。例えば，プルシアンブルーをナノ粒子化するこ とで，ゼオライトの $67 \sim 1400$ 倍のセシウム吸着能力のあ るセシウム吸着剤が開発されている13,14)。

トバモライトはケイ酸カルシウム水和物の一種であり, 一般式は $5 \mathrm{CaO} ・ 6 \mathrm{SiO}_{2} ・ 5 \mathrm{H}_{2} \mathrm{O}$ で表される。水熱処理によ り人工的に合成される多孔性の物質で, 比表面積は 50 $\mathrm{m}^{2} / \mathrm{g}$ を超える。この多孔性の表面が陽イオン吸着性を示 すため，セシウム等をイオン交換で除去できる。また，含 まれるカルシウムをナトリウムで部分置換し，あわせてシ リコンをアルミニウムで置換することで, 高い陽イオン交 換性能を発現するとともに，セシウムへの選択性を示すこ とが見出されている15,16)。

\section{3 セシウム・ストロンチウムの除去における課題}

これらの種々の材料を用いた除染が，一部は既に進めら れている。高濃度污染された冷却水からの放射性物質, 主 にセシウムの除去について, キュリオン, サリー等ではゼ オライトを利用して回収し，その後セシウム等を分離回収 して高レベルの放射線廃棄物として処理される。しかし， 例えば放射性セシウムを $1 \%$ 含むケイ酸塩鉱物をドラム 缶に詰めた放射性廃棄物を考元ると，その中心温度が崩壊 熱のために数 $100^{\circ} \mathrm{C}$ に達するとの試算がある。従って, 高濃度で放射性物質を回収できることが重要かというと， 必ずしもそう言い切れないのがわかる。また，粘土鉱物に 固定化されたセシウムは, 容易に回収することが難しく, これらを体内に取り込んだ海洋性生物は内部被爆による影 響を無視できなくなることも，容易に想像がつくであろ う。居住地域や田畑, 公共設備等における除染は速やかに 行うことが契緊の課題である。その一方で, それ以外の地 域や水系では, 低量でセシウム等が存在していてもそれが 飛散しないように固定化し，自然界の生物への取り込反を

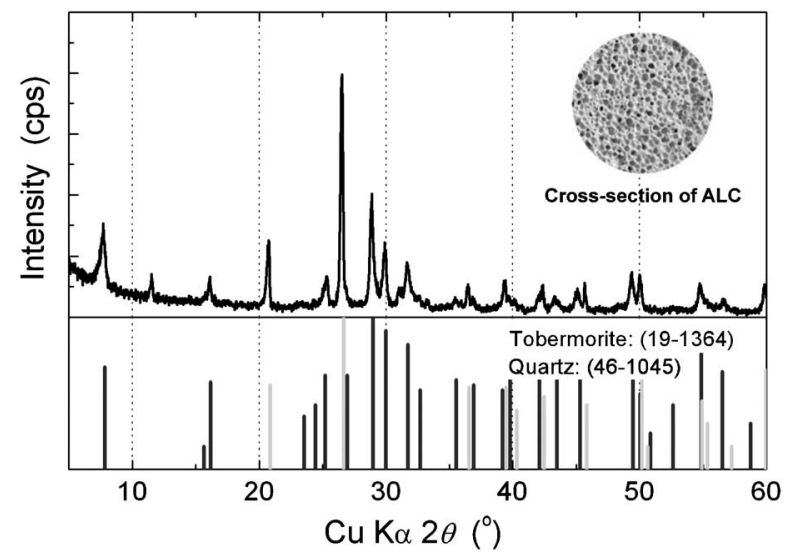

Fig. 1 XRD pattern of an autoclaved lightweight concrete (ALC).

極力低減するような回収方法を取り入れることも $1 つ の$ 選択肢として考えられる。

\section{4 研究の目的}

セシウム等の除去, 特に水系からの除去に扔いては, 単 純に高い除去性能が重要というわけではない。安全な濃度 でセシウムを水中より取り除き，再放出が生じず，かつ回 収が容易であることが必要である。さらに，現状の放射性 廃棄物の処理関連の状況を鑑反ると，長期にわたり環境中 に放置できる耐久性も併せ持つ材料であることが望まし い。これらの条件に合致する材料の 1 つに，トバモライ 卜を主成分として構成される「軽量気泡コンクリート材 (ALC)」が挙げられる。ALC は建築物の外壁材に多く利 用されている建材である。Fig. 1 は ALC の細孔構造と XRD パターンを示している。パターンには主相であるト バモライト相と骨材である石英相が観察される。廃棄物と しての利用を考えた場合, 数 $\mathrm{mm}$ 厚の石膏ボードに比べ ると $50 \mathrm{~mm}$ 以上の厚さをもつ材料であることから, 装飾 された表面を軽く削ることで元の厚みをあまり損なうこと なく利用できる。また，建材であるので，工業規格として 十分な材料強度を兼社備えている。製品だけでなく廃棄物 の利用まで視野に入れると, 安価で大規模な利用が可能で ある。これらの点をふまえ, 本研究では広く利用されてい る軽量気泡コンクリート廃材を用いた，高いセシウム・ス トロンチウム吸着能を持つ新規イオン交換材料を開発する ことを目的とした。

\section{2. 実験方法}

\section{$2.1 \mathrm{ALC}$ の水酸化ナトリウム処理}

既報 ${ }^{15,16)}$ のように，トバモライトは構造中のカルシウム を部分的にナトリウムに置換することで，セシウム除去性 能を発現する。まず，0.1〜 $1.67 \mathrm{M}$ の水酸化ナトリウム水 溶液を調製し，粉砕して $150 \mu \mathrm{m}$ アンダーに穊い分けした $\mathrm{ALC}$ 粉末と水酸化ナトリウム水溶液の固液比が $\mathrm{S} / \mathrm{L}=0.2$ $\mathrm{g} / \mathrm{mL}$ となる条件で, 水熱容器内の充填率が $60 \%$ となる 
Table 1 Composition ion and its concentration of typical sea water

\begin{tabular}{cccc}
\hline \hline \multicolumn{2}{c}{ Cation } & \multicolumn{2}{c}{ Anion } \\
\hline Ions & $\begin{array}{c}\text { Concentration } \\
(\mathrm{ppm})\end{array}$ & Ions & $\begin{array}{c}\text { Concentration } \\
(\mathrm{ppm})\end{array}$ \\
\hline $\mathrm{Na}^{+}$ & 10556 & $\mathrm{Cl}^{-}$ & 18980 \\
$\mathrm{Mg}^{2+}$ & 1272 & $\mathrm{SO}_{4}{ }^{2-}$ & 2649 \\
$\mathrm{Ca}^{2+}$ & 400 & $\mathrm{HCO}_{3}{ }^{-}$ & 140 \\
$\mathrm{~K}^{+}$ & 380 & $\mathrm{Br}^{-}$ & 65 \\
\hline
\end{tabular}

ように仕込んだ。この混合物を， $180^{\circ} \mathrm{C}$ の恒温槽中で 3〜 48 時間熱処理した。冷却後, 固液分離, イオン交換水を 用いた水洗処理を施し, $50^{\circ} \mathrm{C}$ の恒温槽で乾燥して, 目的 である水酸化ナトリウム処理 ALC 粉末が得られた。

また，ALCバルク体については， $10 \mathrm{~mm} \times 10 \mathrm{~mm} \times 10$ $\mathrm{mm}$ に削りだした試料を，ALC粉末で最もセシウム除去 性能が高い条件で水酸化ナトリウム中での水熱処理を施し た。

\section{2 セシウム・ストロンチウム除去実験}

塩化セシウム，および塩化ストロンチウム六水和物を用 いて所定の濃度のセシウム水溶液, ストロンチウム水溶 液, およびセシウム・ストロンチウム混合水溶液を調製し た。除去実験は, バッチ法で試料/溶液比が $0.5 \mathrm{~g} / 100 \mathrm{~mL}$ となる条件で, 室温下, 振盪機の振動数が $150 \mathrm{~s}^{-1}$ で所定 の時間反応させた。反応後の試料は遠心分離機を用いて, 固液分離された。溶液中のイオン濃度は, 原子吸光分析装 置 [AA-6800，侏島津製］を用いて，対象であるセシウ ムとストロンチウムに加えて, ナトリウムとカルシウムを 分析した。また, 回収された粉末は, 乾燥した後にペレッ 卜状に成形して, 蛍光 X 線分析装置 [ZSX PrimusII, 秼 リガク製】を用いて組成分析した。

\section{3 模擬海水中からのセシウム・ストロンチウム除去実 験}

塩化ナトリウム, 炭酸水素ナトリウム, 塩化カリウム, 臭化カリウム, 塩化マグネシウム, 抢よび硫酸カルシウム を用いて, Table 1 に示す海水組成となる水溶液を調製 し, 模擬海水とした。この模擬海水を溶媒として, 2.2 と 同様に $50 \mathrm{ppm}$ セシウム, $25 \mathrm{ppm}$ ストロンチウム, 抢よ び $50 \mathrm{ppm}$ セシウムと $25 \mathrm{ppm}$ ストロンチウムを含む模擬 海水を調製した。除去実験は，2.2 と同じ条件で反応時間 を 24 時間に固定して行った。反応後の試料は 2.2 と同様 に溶液と固体に分けて分析した。

\section{3. 結果と考察}

\section{1 水酸化ナトリウム処理の影響}

水熱処理を 24 時間施した ALC 粉末の XRD パターンを Fig. 2 に示す。水酸化ナトリウム濃度が高いほど石英の ピーク強度が低下した。一方, トバモライトのピークに大

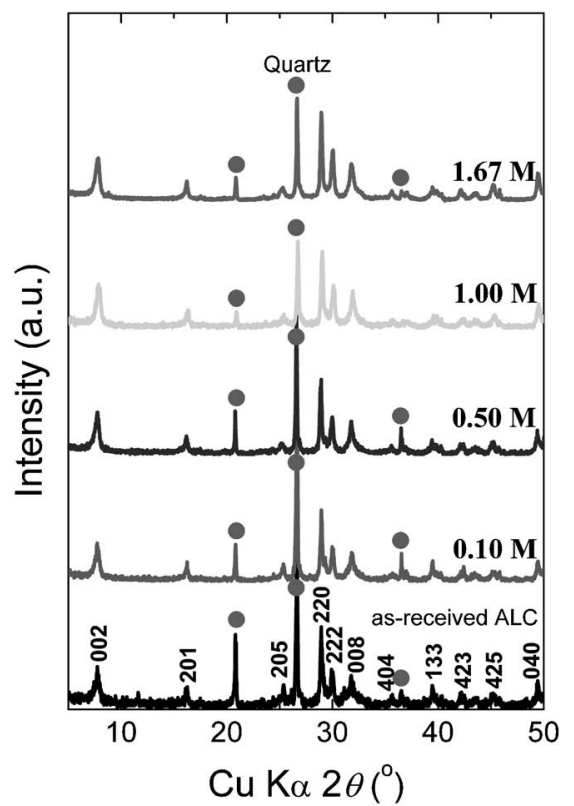

Fig. 2 XRD patterns of $\mathrm{NaOH}$ treated ALC powders.
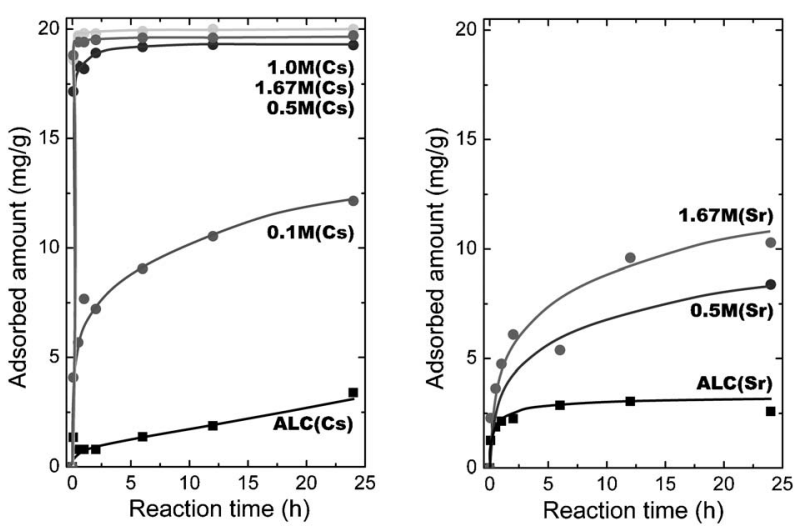

Figs. 3 Adsorbed amount of $\mathrm{Cs}$ and $\mathrm{Sr}$ by various $\mathrm{NaOH}$ treated ALC powders.

きな変化はなかった。XRFでの組成分析から，水酸化ナ トリウム濃度が高いほどナトリウム量が増加し， $1.67 \mathrm{M}$ で水熱処理した試料では $5 \%$ の含有量であった。それに ともない, カルシウム量は減少し, $1.67 \mathrm{M}$ で水熱処理し た試料では $5 \%$ 減少した。従って, トバモライトのピー クシフトは観察されなかったが，トバモライトのカルシウ ムの一部がナトリウムに置換したことが示唆された。

\section{$3.2 \mathrm{ALC}$ 粉末のセシウム・ストロンチウム除去性能}

水熱処理を 24 時間施した ALC 粉末のセシウムとスト ロンチウムの除去量の経時変化を Fig. 3 に示す。セシウ ムの除去量は未処理の ALC 粉末が $3 \mathrm{mg} / \mathrm{g}$ であった。こ れに対して，0.1 M の水酸化ナトリウムで処理した試料は, $12 \mathrm{mg} / \mathrm{g}$ となり, 未処理の ALCの 4 倍以上の除去能を示 した。さらに高い濃度の水酸化ナトリウムで処理した試料 は， $0.5 \sim 2$ 時間で吸着が飽和してしまい，設定した 100 
Table 2 Removed amount of $\mathrm{Cs}$ or $\mathrm{Sr}$, released amount $\mathrm{Na}$ and $\mathrm{Ca}(\mathrm{AA})$, and included amount of $\mathrm{Cs}$ or $\mathrm{Sr}(\mathrm{XRF})$ for various samples

\begin{tabular}{lccccc}
\hline \hline \multicolumn{1}{c}{ Sample } & $\begin{array}{c}\text { Obj. } \\
\text { ion }\end{array}$ & $\begin{array}{c}\text { Removed } \\
\text { amount } \\
(\mathrm{mg})\end{array}$ & $\begin{array}{c}\text { Released } \\
\mathrm{Na} \\
(\mathrm{mg})\end{array}$ & $\begin{array}{c}\text { Released } \\
\mathrm{Ca} \\
(\mathrm{mg})\end{array}$ & $\begin{array}{c}\text { Bulk } \\
\text { amount } \\
(\mathrm{mg})\end{array}$ \\
\hline ALC powder & $\mathrm{Cs}$ & 1.7 & - & - & - \\
ALC powder & $\mathrm{Sr}$ & 1.2 & - & - & - \\
Na ALC powder & $\mathrm{Cs}$ & 8.4 & 7.0 & 0.02 & 7.0 \\
Na ALC powder & $\mathrm{Sr}$ & 4.2 & 10.4 & 0.07 & 8.8 \\
ALC bulk & $\mathrm{Cs}$ & 1.1 & 0.25 & 1.8 & - \\
ALC bulk & $\mathrm{Sr}$ & 0.1 & 0.22 & 2.1 & - \\
Na ALC bulk & $\mathrm{Cs}$ & 6.4 & 11.9 & $\mathrm{Tr}$ & - \\
Na ALC bulk & $\mathrm{Sr}$ & 4.8 & 8.9 & $\mathrm{Tr}$ & - \\
\hline
\end{tabular}

$\mathrm{ppm}$ 溶液の除去率は $100 \%$ となった。一方，ストロンチ ウムの除去量は未処理の ALC 粉末が $3 \mathrm{mg} / \mathrm{g}$ であった。 セシウムと同様に処理する水酸化ナトリウムの濃度の増加 にともない除去量は増加し, $1.67 \mathrm{M}$ の水酸化ナトリウム で処理した試料は， $10 \mathrm{mg} / \mathrm{g}$ になった。しかし，セシウ ムの場合とは異なり，除去率は 50\%であった。

セシウムについて，1.67 M の水酸化ナトリウム処理で の最適時間を検討した。その結果, 反応時間 $3 \mathrm{~h}$ で飽和量 の $90 \%$ の除去能を示し， $12 \mathrm{~h}$ で飽和することがわかっ た。そこで, ALC 粉末の水酸化ナトリウム処理時間は $3 \mathrm{~h}$ とした。あわせて，バルク体の処理時間を $24 \mathrm{~h}$ とした。

Table 2 に $100 \mathrm{ppm}$ セシウム水溶液と $50 \mathrm{ppm}$ ストロン チウム水溶液からの 24 時間での除去結果を, $1.67 \mathrm{M}$ の水 酸化ナトリウム処理 ALC 粉末と末処理の ALC 粉末につ いて，それぞれ示す。未処理の ALC 粉末に比べて，水酸 化ナトリウム処理 ALC 粉末は, セシウムでは 4.9 倍, ス トロンチウムでは 3.5 倍に除去量が増加した。また,

$\mathrm{XRF}$ で求めた回収物中のセシウム量は溶液から求めた除 去量と一致した。しかし, 回収物中のストロンチウム量は 溶液から求めた除去量の 2 倍であった。少なくともセシ ウムについてはよく一致することがわかった。また，除去 時のカウンターイオンは, 未処理の場合はカルシウムであ り，水酸化ナトリウム処理試料ではナトリウムであること がわかった。

以上の結果から, ALC 粉末を水酸化ナトリウムで処理 することで, $\mathrm{Na}$ 部分置換型のトバモライトが生成するこ とと, このトバモライトは易交換なカルシウムがナトリウ ムに置換されたため，2 価のストロンチウムよりも 1 価の セシウムの除去能力が高いことが明らかになった。

$0.5 \mathrm{M}$ の水酸化ナトリウムで処理した試料と $1.67 \mathrm{M}$ の 水酸化ナトリウムで処理した試料の吸着等温線を Fig. 4 に示す。どちらの試料についても, 吸着等温線は Langmuir モデルで精度よく近似できた。近似曲線より算出し た飽和吸着量は， $0.5 \mathrm{M}$ の場合が $0.35 \mathrm{mmol} / \mathrm{g}, 1.67 \mathrm{M}$ の場合が $0.57 \mathrm{mmpl} / \mathrm{g}$ であった。これらの值は, 未処理

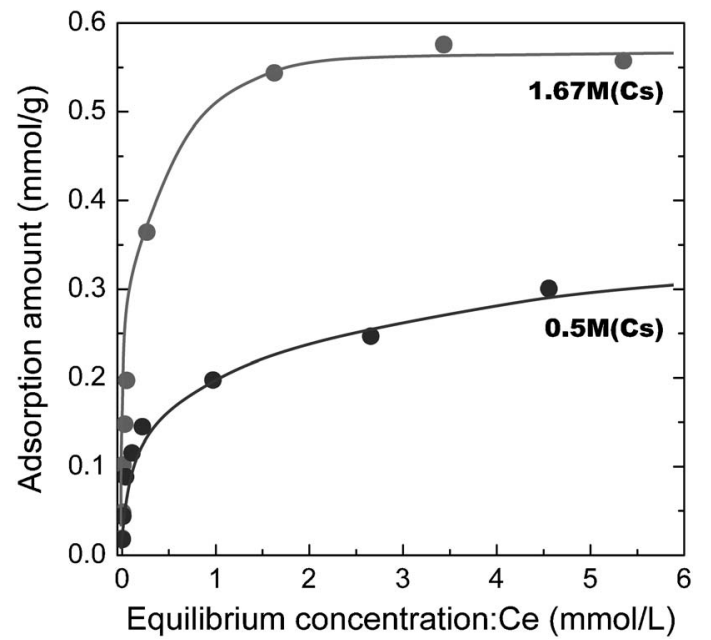

Fig. 4 lon-exchange isotherms of $\mathrm{NaOH}$ treated ALC powders.

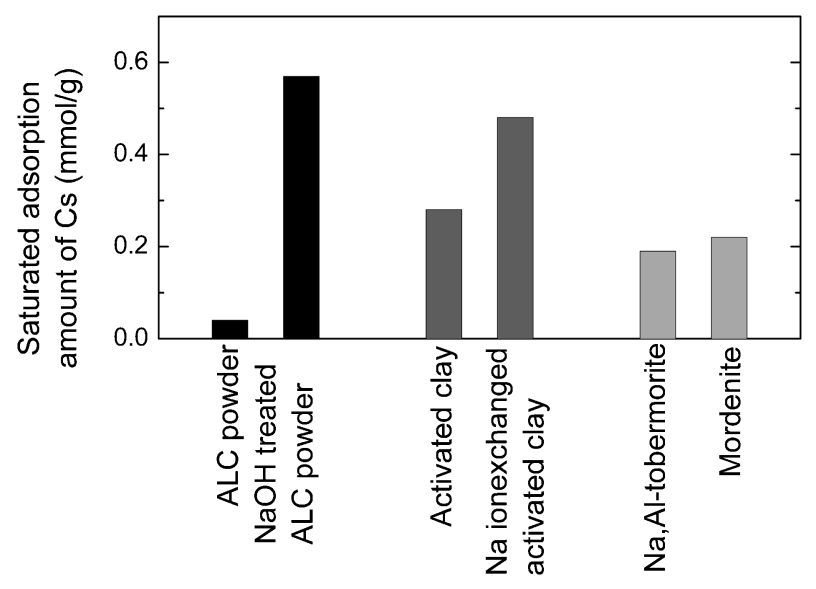

Fig. 5 Saturated adsorption amount of Cs by various samples.

の ALC 粉末の飽和吸着量の 9 倍, および 16 倍であり, セシウム除去能が未処理の ALC よりも大きく向上したこ とがわかった。

Fig. 5 に, 本研究の ALC 粉末のセシウムの飽和吸着量 を, 活性粘土, ナトリウム, アルミニウム置換トバモライ ト ${ }^{16)}$ ，抢よびセシウムの吸着能力が高いモルデナイト型 ゼオライトとともに示す。ALC 粉末のセシウム吸着能は 低いが水酸化ナトリウム処理により大きく性能が向上し, その能力は既報のナトリウム，アルミニウム置換トバモラ イトやモルデナイト型ゼオライトの 2 倍以上であった。 また，高いイオン交換能を持つナトリウムイオン交換型活 性粘土よりも高い值を示した。粉末べースでの比較では, 既存の材料を大きく凌駕するセシウム吸着能であることが わかった。

\section{$3.3 \mathrm{ALC}$ バルク体のセシウム・ストロンチウム除去性能}

ALCバルク体のセシウムとストロンチウムの除去性能 は前出の Table 2 に合わせて示されている。未処理の試 料のセシウム除去量は, 粉末では $1.7 \mathrm{mg}$ であったものが 
バルク体では $1.1 \mathrm{mg}$ であった。一方，ストロンチウム除 去量は, 粉末では $1.2 \mathrm{mg}$ であったものがバルク体では $0.1 \mathrm{mg}$ であった。バルク体では粉末よりも反応面積が大 きく低下する。このためにストロンチウムは $1 / 10$ 以下の 除去量になったが，セシウムは $33 \%$ 程度の除去能の低下 であった。これは, トバモライト相がセシウムとの親和性 が高いためと考えられる。また，この時のカウンターイオ ンはいずれもカルシウムであった。しかし，カルシウムの 溶出量は除去されたセシウムやストロンチウムよりも多か った。

水酸化ナトリウム処理の ALC バルク体の除去性能は, セシウムで $6.4 \mathrm{mg}$ ，ストロンチウムで $4.8 \mathrm{mg}$ であった。 水酸化ナトリウム処理の ALC 粉末に比べて，セシウムは $25 \%$ ほど小さな值であったが，ストロンチウムはわずか に大きな值であった。カウンターイオンはどちらもナトリ ウムであった。ナトリウムの溶出量は除去されたセシウム やストロンチウムの $2 \sim 4$ 倍であった。

以上の結果から, ALCバルク体でも水酸化ナトリウム 処理を施した場合は粉末と同程度のセシウムとストロンチ ウムの除去性能が発現することが示された。しかしなが ら, 実際の除去量以上にカウンターイオンが溶出してい た。従って, より実際の回収条件に近いイオン强度下での 除去性能の評価が必要であると示唆された。

\section{4 模擬海水中からのセシウム・ストロンチウム除去}

$1.67 \mathrm{M}$ の水酸化ナトリウムで処理した ALC 粉末打よ びバルク体を用いて模擬海水中のセシウムとストロンチウ 厶を除去した結果を Fig. 6 に示す。ALC 粉末およびバル ク体のどちらも, 単独の水溶液の場合と比べて, セシウム とストロンチウムのどちらについても除去量が低下した。 ALC 粉末ではセシウムが $1 / 5$, ストロンチウムが $1 / 70$ と なり，ALCバルク体ではセシウムが $1 / 18$, ストロンチウ ムが $1 / 240$ となった。これは, Table 1 に示すように共存 する陽イオンがセシウムの $50 \mathrm{ppm}$ ，ストロンチウムの 25 ppm に比べて高濃度であることが原因である。

一方, Fig. 6 からも明らかなように, 単独の場合に比 ベるとセシウムの選択性がストロンチウムよりも大幅に高 くなっている。ALC 粉末は単独では 2 倍だったが，海水 中からでは 30 倍に, ALCバルク体は単独では 1.1 倍だっ たが，海水中からでは 18 倍になった。さらにセシウム・ ストロンチウム混合模擬海水からの除去を行ったところ, セシウムはストロンチウムの 8.3 倍の除去量であった。こ れらの結果から, 水酸化ナトリウム処理された ALC は, 特に海水中からの高いセシウムの選択性を示すことが明ら かになった。

セシウムを除去した ALC 粉末と ALCバルク体を, 模 擬海水中に保持したところ，24 時間後のセシウムの再放 出濃度は検出限界以下であった。従って, 目的であるセシ ウムを固定化可能なイオン交換材料が開発できたと考えら れる。

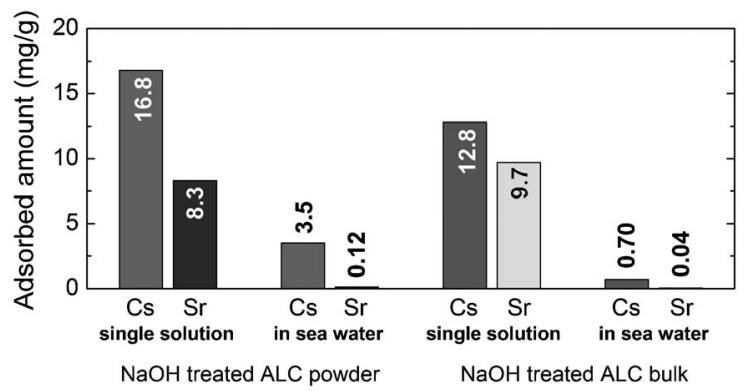

Fig. 6 Adsorbed amount of $\mathrm{Cs}$ and $\mathrm{Sr}$ by various $\mathrm{NaOH}$ treated ALC powders.

\section{4. まとめ}

軽量気泡コンクリート材（ALC）を基材に用いた，セ シウム抢よびストロンチウムの吸着イオン交換材料を開発 したところ，以下のことが明らかになった。

・トバモライトを含むALC はセシウムとストロンチウム の吸着除去性能を示したが，水酸化ナトリウム処理を施 すことで, 飽和吸着量がセシウムで $0.57 \mathrm{mmol} / \mathrm{g}$, ス卜 ロンチウムで $0.12 \mathrm{mmol} / \mathrm{g}$ に増加した。

・水酸化ナトリウム処理 ALC は, 既存のゼオライトや粘 土鉱物よりも高いセシウム除去性能を示した。

・水酸化ナトリウム処理 ALC は, 海水中からもセシウム の除去が可能であった。回収量は少なかったが，崩壊熱 の関係やセシウムの再放出がないことから，長期間の除 去に利用可能と考えられる。

本研究で開発した水酸化ナトリウム処理 ALC バルク体 は, 固定化性能の長期維持性が確立されることで, 水系に おける污染の低減に貢献できると考えられる。セシウムを 低回収量で海水中に保持することで, 海洋性生物の経口摂 取による内部被曝を抑制し, かつ外部被爆の影響を低減さ せる。その結果として, 漁場等が一日でも早く回復するこ とを切望する。

\section{謝辞}

本研究の一部は, 日本イオン交換学会で平成 23 年度に 募集された「放射性物質の回収・固定化プロジェクト」か らの資金により実施された。関係各位に深く感謝する。

\section{References}

1) K. O. Buesseler, Science, 338, 480 (2012).

2) E. Brown, Los Angels Tomes, February 25 (2013).

3) E. M. Flanigen and L. B. Sand, (ed.) "Molecular Sieve Zeolite-I, II" (Adv. Chem. Series, 101, 102), ACS Press, New York (1971).

4) J. L. Boettinger and D. W. Ming, "Soil mineralogy with environmental applications”. SSSA Book Series No. 7, Soil Sci. Soc. Am., Madison (2002), pp. 585-610.

5) G. W. Brindley and G. Brown, (ed.) "Crystal structures of clay minerals and their X-ray identification”, Miner. Soc., London (1980). 
6) B. L. Sawhney, Proceed. Soil Sci. Soc. Am., 28, 183 (1964).

7) A. nakao, Y. Thiry, S. Funakawa and T. Kosaki, Soil Sci. Plant Nutririon, 54, 479 (2008).

8) R. Bouabid, M. Badraoui and P. R. Bloom, Soil Sci. Soc. Am. J., 55, 1493 (1991)

9) K. Morimoto, K. Tamura, Y. Umehara, H. Sato and A. Yamagishi, Chem. Lett., 40, 867 (2011).

10) C. E. Weaver, "Clays, Muds and Shales", Elsevier, Amsterdam (1989) pp. 819.

11) M. Miyake, T. Yoshida, H. Uchida, M. Ozawa and T.
Suzuki, Chem. Mater., 3, 572 (1991).

12) M. Miyake, T. Suzuki and T. Suzuki, Chem. Mater., 5, 1327 (1993).

13) N. L. Torad, M. Hu, M. Imura, M. Naito and Y. Yamauchi, J. Mater. Chem., 22, 18261 (2012).

14) M. Hu, N. L. Torad and Y. Yamauchi, Eur. J. Inorg. Chem., 2012, 4795 (2012).

15) S. Komarneni and D. M. Roy, Science, 221, 647 (1983).

16) O. P. Shrivastava and S. Komarneni, Cement Concr. Res., 24, 573 (1994).

\title{
Review
}

\section{Development of cesium ion exchange materials from autoclaved lightweight concrete (ALC) materials}

\author{
Yoshikazu KAMESHIMA*, Takuma TSUTSUMI, \\ Shunsuke NISHIMOTO and Michihiro MIYAKE \\ Department of Material and Energy Science, Graduate School of Environmental and Life Science, Okayama University, \\ 3-1-1 Tsushima-naka, Kita-ku, Okayama-shi 700-8530, Japan
}

(Received April 1, 2013)

\begin{abstract}
The material for removing, recovering and fixing of the cesium etc. which were emitted by the accident of the Fukushima Daiichi nuclear power plant into environment is needed. Authors' research group has developed a new cesium adsorption and fixation material based on an autoclaved lightweight concrete (ALC) that consists of tobermorite. High cesium removal performance is revealed by hydrothermal treatment of a tobermorite with sodium hydroxide. In this paper, cesium and strontium removal performance of the powder and the bulk of this $\mathrm{NaOH}$ treated ALC sample and the removal performance of cesium and strontium from the sea water by these samples are explained.
\end{abstract}

Keywords: Autoclaved lightweight concrete (ALC), Tobermorite, Ion exchange, Cesium, Adsorption 